\title{
Microspherules-Bearing White Sandstone: Implication of Cosmic Impact Event near Jurassic-Cretaceous Boundary in West Central Sinai, Egypt
}

\author{
Hanan S. Badawy, Ahmed M. Zayed, Mohamed G. Shahien \\ Geology Department, Faculty of Science, Beni-Suef University, Beni-Suef, Egypt \\ Email: h.s.badawy2000@gmail.com, Dr.hanansayed@science.bsu.edu.eg
}

Received 29 May 2016; accepted 22 July 2016; published 25 July 2016

Copyright (C) 2016 by authors and Scientific Research Publishing Inc. This work is licensed under the Creative Commons Attribution International License (CC BY). http://creativecommons.org/licenses/by/4.0/

(c) () D Den Access

\section{Abstract}

The presence of glass microspherules enclosing relict grains, shattered quartz and silicon carbide in white sandstone beds near the Jurassic-Cretaceous boundary in west central Sinai indicates a cosmic impact event. Characterization of the impact microspherules and proposing a reasonable scenario for their origin are the aims of this work. Field observations, optical, binocular, scanning electron and high-resolution transmitted electron microscopy investigations and chemical analyses were carried out. The study revealed that glass microspherules have high $\mathrm{Al}_{2} \mathrm{O}_{3}$ and $\mathrm{FeO}$ contents and low $\mathrm{CaO}$ and $\mathrm{MgO}$ contents. The high content of $\mathrm{Al}_{2} \mathrm{O}_{3}$ indicates that the source of microtektite-like microspherules is attributed to the melting of a clay-rich sandstone and carbonaceous matter, while the high content of $\mathrm{FeO}$ indicates admixing with projectile matter. The reaction between silica and carbon was carried out under conditions of high temperature $\left(T>1000^{\circ} \mathrm{C}\right)$ and carbon $(\mathrm{C} / \mathrm{Si}>\mathrm{1})$ which resulted in the production of silicon carbide with microdiamond intergrowth. Consequently, this intergrowth is in accordance with the impact origin via rapid condensation and growth within a vapor phase. In spite of the fact that no source crater has been recognized to date in the study area, the authors propose at least a single cosmic impact event scenario for the recorded glass microspherules in west central Sinai. The impact excavated the Paleozoic siliciclastic sedimentary rocks and then the glass microspherules showered the area of study. The deposition of microtektite-like glass particles within the white sandstone beds of the Malha Formation took place in the fluvial plain terrestrial environment. This setting precluded severe post-depositional reworking, yielding preservation of the glass particles in a primary layer. Eventually, lateral migration of the braided channels led to the reworking of the microspherules layer and the spatial dispersal of the shattered quartz. 


\section{Keywords}

\section{Impact Glass, Microtektites, Ejecta, Nubian Sandstone, SiC}

\section{Introduction}

The most valuable source of extraterrestrial material falling to the Earth is represented by microscopic Cosmic Dust particles (CD) together with larger meteorites. The CD is derived from a collision in the asteroid belt and from materials ejected from the surface of comets [1]. Cosmic dust input to Earth, in the form of Interplanetary Dust Particles (IPDs) and Micrometeorites (MMs), strongly prevails over the meteorites [2]. The extraterrestrial material in deposits can be traced physically, chemically and isotopically. Physical tracers include actual meteorites, cosmic spherules, impact spherules, spinels and ocean-impact melt debris [1].

Glassy microspherules have been described in numerous settings, but much of the studied spherules are of unproven meteoritic or even impact origin [1]. In addition to the work on impact spherules, a number of workers attempted to study cosmic glass spherules. The cosmic glass spherules represent wholly melted spherical particles of the MMs. They are produced by the aerodynamic melting of sub-millimeter fragments of asteroid and comet that penetrate the atmosphere at a velocity ranging from 11 to $72 \mathrm{~km} / \mathrm{s}$ without disintegration [2]. Otherwise, the so-called ablation spherules are formed whilst the flying cosmic bodies through the Earth's atmosphere are ablated, i.e., their surfaces are heated, they are dissolved, evaporated and oxidized, and the melt is blown off under the force of the incoming air [3]. The higher velocity atmospheric entry of meteoroids affects the physical properties of cosmic dust [4].

On the other hand, impact glass spherules condense from a meteorite impact. They form together with shocked minerals the so-called impact ejecta, which are rarely recognized in the terrestrial geologic record. The ejecta may possibly include impact microdiamonds or be enriched with shocked quartz with elevated C and Ir contents [5]. The shocked mineral grains are characterized by various structural and phase changes indicating high shock pressure and temperature generated by the impact of extraterrestrial bodies. These changes are represented by planar micro-deformation structures categorized as Planar Deformation Features (PDFs) and Planar Fractures (PFs) [6]-[9]. In some instances, it is hard to distinguish between the cosmic and impact glass spherules. Nevertheless, such types of glass spherules represent the most common physical traces of extraterrestrial matter in sediments and signify cosmic impact event.

Cosmic impact denotes to a collision of a cosmic body either with the Earth's surface, bringing out a crater, or with its atmosphere, creating an aerial burst [10]. The factors affecting the form of impact craters and the resultant ejecta are the size and velocity of the impactor and the geology of the target surface. Impact craters reveal hypervelocity impact event and they form when a projectile is huge and cohesive enough to penetrate the Earth's atmosphere with little or no slowing and to hit the earth at nearly its original cosmic speed $(>11 \mathrm{~km} / \mathrm{s})$ [11]. Alternatively, penetration craters form when the smaller diameter projectile is slowed down by passage through the Earth's atmosphere (e.g., the Sikhote-Alin crater field in Russia formed from a meteorite shower in 1947). Aerial burst is taken as a significant category of impact episodes that either doesn't form craters, or which forms very shallow structures that are simply erased [11]. However, visible impact craters are less common because they become eroded, hidden or altered by tectonic over time. In the case of cosmic impact on the ground, the consequential plume vapor comprises vapor, glass spherules, shocked and unshocked rock fragments and angular melted particles [10]. While the air burst plume vapor, which produced via atmospheric impact, leads to major melting of only a few centimeters of the Earth soil by the hypervelocity jet fall to the earth from the atmospheric bang and produces glass spherules and angular melted particles, but simply lacks the mechanically shocked rocks [10].

In general, impact glasses or the so-called tektites are derived by melting of terrestrial material and rapid cooling [12]. They are grouped by size into tektites $(>1000 \mu \mathrm{m})$ and microtektites $(<1000 \mu \mathrm{m})$. The elevated amount of volatiles (water vapor) from shock porous target rocks leads to the dispersal of shocked-produced impact melt over large distances and forms microscopic microtektites glass particles [13]. Nevertheless, the microtektites are formed by the condensation of a two-phase mixture, where the vapor and the melt coexist [14]. The tektites can be correlated by their chemical constitution, age, petrographical and physical characteristics 
over large regions of the world known as "strewn fields" [15]. In some instance, the strewn field can be ascribed to an impact crater [16] [17]. The main strewn fields of the tektites are identified in the Cenozoic where they occur in the Libyan Desert (no crater has ever been found, Late Eocene age); Central Europe (linked to Ries Crater in Germany, Miocene age); Ivory Coast (linked to Bosumtwi Crater in Ghana, West Africa, Pleistocene age); North America (linked to the Chesapeake Crater, Late Eocene age) and Australia (source crater still unknown, Pleistocene age). The strewn field of the Libyan Desert Glass (LDG) was discovered in the southern Great Sand Sea (southwestern Egypt) since 1934. Reference [18] has discovered the latest LDG occurrence at about $50 \mathrm{~km}$ southward of the main occurrence in the Great Sand Sea. Mesozoic sandstone (Nubian Sandstone) is often cited as the possible terrestrial precursor of LDG [18]. LDG did not ascribe to meteorite impact but to the comet air burst [18].

Although few works have been carried out on meteorite impact in Egypt one of the recorded Cenozoic craters in Africa was identified in southern Egypt at Gebel Kamil [19]. Gebel Kamil crater was formed about 5000 yrs ago [20]. Large number of metallic $\left(\mathrm{Fe}_{3} \mathrm{O}_{4}\right)$ micro-spherules has been found near Kamil Crater, while glass micro-spherules were very rare and small in size [21].

The discovery of tektites at the Cretaceous-Tertiary (K/T) boundary has triggered a search for pre-Cenozoic tektite events in the sedimentary record [22]. In this study, we report for the first time the presence of impact glass microspherules in Early Cretaceous white sandstone beds in west central Sinai. The study is intended to characterize the impact microspherules and to propose a reasonable scenario for their origin.

\section{Materials and Methods}

Stratigraphic section comprising the recognized glass microspherules was measured and studied in detail from an exposure located in the west central Sinai. We collected fresh samples from the Early Cretaceous white sandstone beds and performed binocular and optical microscopy investigations on representative thin sections and friable sandstone samples. A Nikon Eclipse (LV 100 POL) polarizing microscope equipped with a digital camera and software was utilized to investigate the micro-texture of the impact glass microspherules and white sandstone samples. A binocular stereomicroscope equipped with a digital camera and software was used to investigate the grains of the weakly cemented sandstone samples enriched with the glass particles.

Chemical analyses and description of mineral grain surface were carried out using a Scanning Electron Microscope (SEM) Model Jeol 6510 JSM, LA equipped with an Energy Dispersive X-ray analyzer (EDX). Glass and silicon carbide particles were picked up from the white sandstone and mounted on carbon tape. They were coated either with gold or platinum and inspected by SEM. The operating conditions were $25-30 \mathrm{kV}$ accelerating voltage and 11 - 19 mm Working Distance (WD).

The internal structures of the glass, quartz and $\mathrm{SiC}$ particles were investigated using a High-Resolution Transmitted Electron Microscope (HRTEM) Model Jeol 1200 JEM and Jeol 2100 JEM. The samples were ground using an agate mortar, then suspended in an ethanol solvent and dispersed using the ultrasonic device and dropped on TEM grids. Operating conditions were $200 \mathrm{kV}$ accelerating voltage and beam current ranges from 109 to $112 \mu \mathrm{A}$.

Optical microscopy, SEM and HRTEM investigations were carried out in the analytical labs of the faculty of science, Beni-Suef University and the National Research Center (NRC) in Dokki, Egypt. A binocular stereomicroscopy investigation was carried out in the analytical labs of the Egyptian Mineral Resources Authority (EMRA) in Dokki.

\section{Results}

\subsection{Stratigraphic Position of the Microspherules and the Host Rocks}

Since Egypt was part of Gondwana, it was affected by the prevalent conditions during the Jurassic period. At that time, large parts of the Gondwana experienced widespread exposure, where fluvial and fluvio-lacustrine systems were prevailing and resulted in the deposition of sand bodies that buried the Gondwana surface beneath [23]. In Egyptian terrains, such sand bodies make up the so-called Nubian Sandstones. However, the Nubian Sandstones were deposited over much of North Africa and Arabia prior to the disintegration of Gondwana as widespread fluvial white sandstone sheets [24]. This succession lies directly above the Precambrian basement and beneath the Cenomanian sedimentary rocks all over Sinai. The upper part of the Nubian Sandstone succession is defined as Malha Formation, which is differentiated into ferruginous sandstone sequence (Late Jurassic 
in age) and white sandstone sequence (Early Cretaceous in age) [24]. White sandstone sequence, which comprises the recognized glass microspherules and deformed quartz grains builds the upper part of the Malha Formation. The well-marked unconformity in the middle part of Malha formation designates the Jurassic-Early Cretaceous boundary [25]. White sandstone of the Malha Formation was deposited in a distal braided plain, which encompassed numerous broad, shallow branching channels that were undergoing processes of active bed form generation and migration [25].

Present field work shows that the stratigraphic section of the upper part of the Malha Formation consists of a cyclic sequence of sandstone and mudstone (Figure 1). The mudstone is made up of dark gray to brown claystone and shale which form thin interbeds and lenses. Contrastingly, sandstone forms thick three units (G1-G3) consisting of friable to semi-friable quartz arenite beds showing faint cross-stratification (Figure 1). The sandstone is grayish white and dominantly fine to medium grained and moderately to well-sorted. In some parts, the sandstone is pebbly to conglomeratic. The topmost part of the white sandstone section is occasionally massive and recrystallized. The recorded glass particles are concentrated in the basal layers of the white sandstone section (Figure 1) while the deformed quartz is scattered through the higher layers of the white sandstone section.

\subsection{Microscopic Observations}

The studied glass particles-bearing sedimentary rocks consist essentially of clear quartz grains that occasionally occur with deformed quartz and microspherules (Figures 2(a)-(d)). Detrital feldspars, mica flakes, heavy and iron oxides mineral grains are also recognized. The quartz grains range in size from fine to medium sand and, occasionally, to gravel. They are dominantly monocrystalline and exhibit uniform extinction. Polycrystalline type exhibiting wavy extinction is also observed. Occasionally, the quartz displays brownish color with a cloudy and grainy appearance resembling shocked toasted quartz (Figure 2(a)). The studied deformed quartz is intensely fractured and displays Boehm lamellae that appear as thin, parallel to subparallel and slightly curved bands being clarified by micro-inclusions (Figure 2(b)). Few of the deformed quartz grains are thought to display planar deformation features (PDFs), which give the appearance of being somewhat curved (Figure 2(c)). Typical PDFs are composed of planar, parallel, narrowly (typically $<2-3 \mu \mathrm{m}$ ) and closely spaced (typically 2 $10 \mu \mathrm{m}$ ) planes of amorphous materials that occur as single or multiple non-decorated sets. The seemingly curved PDFs indicate that grains might be strained after or before the impact deformation [26]. Although, the PDF sets appear curved from a crystallographic point of view they are planar and parallel. Simply the grains appear curved because they follow the c-axis orientation that changes through the grain [26]. Planar fractures (PFs) are also recognized in some of the deformed quartz grains. The recognized PFs are planar thin parallel-walled fissures that occur as single or two sets (Figure 2(d)). Some of fractures display irregular appearance and some are clarified by the fluid inclusion trails (Figure 2(d)).

The recognized microspherules are mostly composed of homogeneous glass, which occasionally encloses anhedral crystals of quartz (Figures 2(e)-(g)). The crystallites increase in number toward the edges of the microspherules. The microscopic quartz mineral inclusions are interpreted as unmelted relicts of the target rock. Some microspherules are partially to completely altered to clay (Figure 2(h)).

The studied glass microspherules are typically less than $1000 \mu \mathrm{m}$ in size, which led to assigning them to be of microtektites category. Some of the studied glass microspherules are black opaque and the non-opaque varieties are transparent to translucent and display multiplicity colors as brown, amber and yellowish brown (Figure 3(a), Figure 3(b)). The microspherules occur in a variety of millimeter-sized splash forms as rods, teardrop-shaped and spheres (Figure 3(a), Figure 3(b)), which are suggestive of their semi-fluid state [27]. The studied glass microspherules are lustrous with shiny, smooth to frosted and rough surface texture (Figure 3(a), Figure 3(b)). Frosted appearance may be due to fine pits and scratches. Some of the studied microspherules contain many large voids concentrated toward their edges (Figure 2(a), Figure 2(b)) while some show a big hollow at their centers (Figures 2(e)-(g)).

The sediments enclosing the glass microspherules are moderately to well-sorted and exhibit grain-supported fabric. The framework components are set in the mottled iron rich matrix. Iron oxide and silica cement overgrowth occur as interstitial pore-filling and coats. Abundance of detrital grains and cement overgrowth of iron and silica in the sandstone points to a diagenetic history. The source of iron oxide mainly attributes to intra-stratal change of iron bearing detrital silicates after deposition [28]. The topmost part of the white sandstone section, quartzite beds, consists of coarse grained, closely packed and recrystallized quartz grains. Secondary silica overgrowth is contributed to the lithification of these beds. 


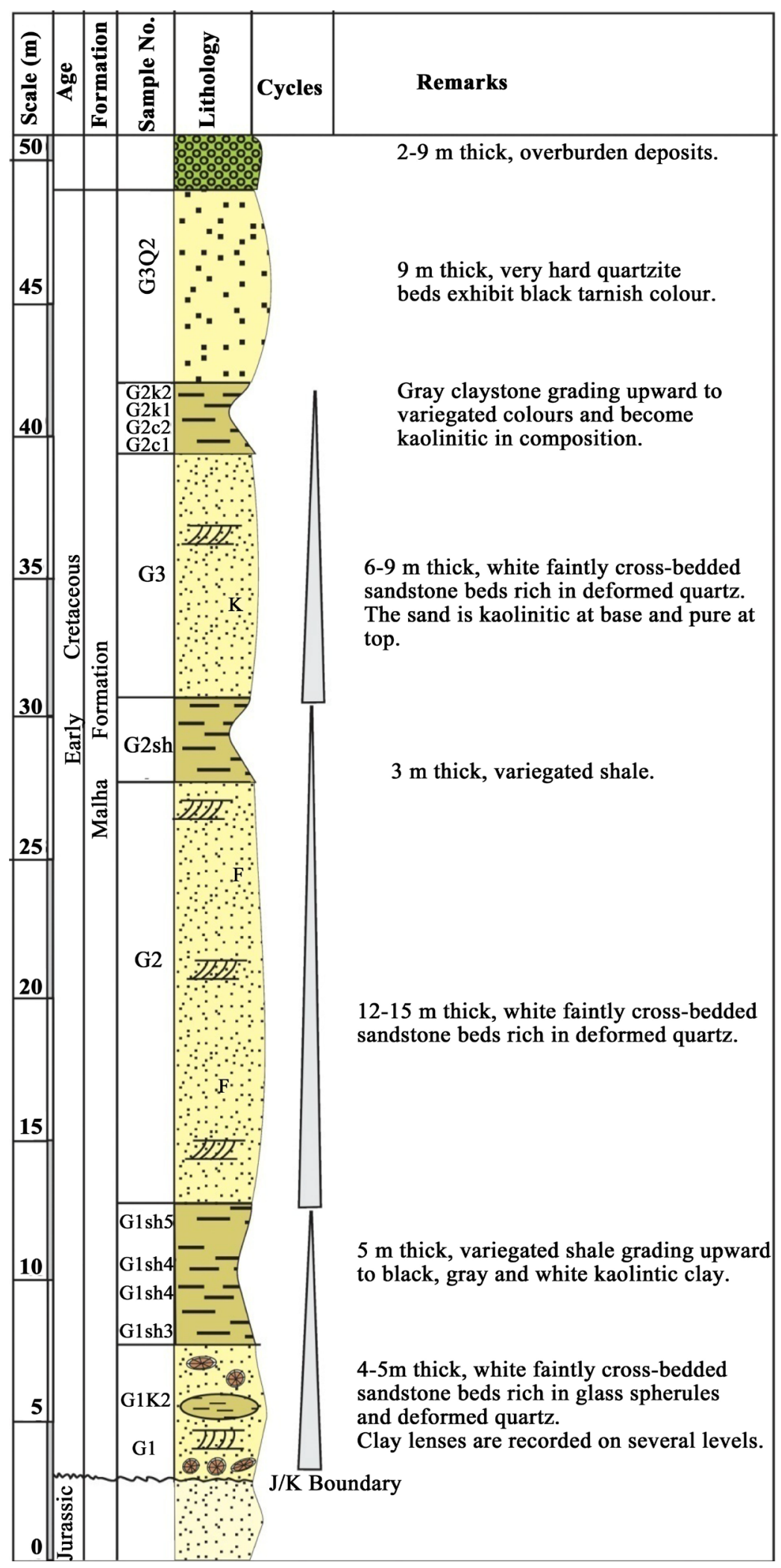

Figure 1. Cyclic sequence of the Malha Formation in west central Sinai. Sequence consists of faintly cross-stratified sandstone beds forming three units (G1-G3) separated by mudstone interbeds. Notice, glass particles are concentrated in the basal layer of the quartz arenite sandstone. 

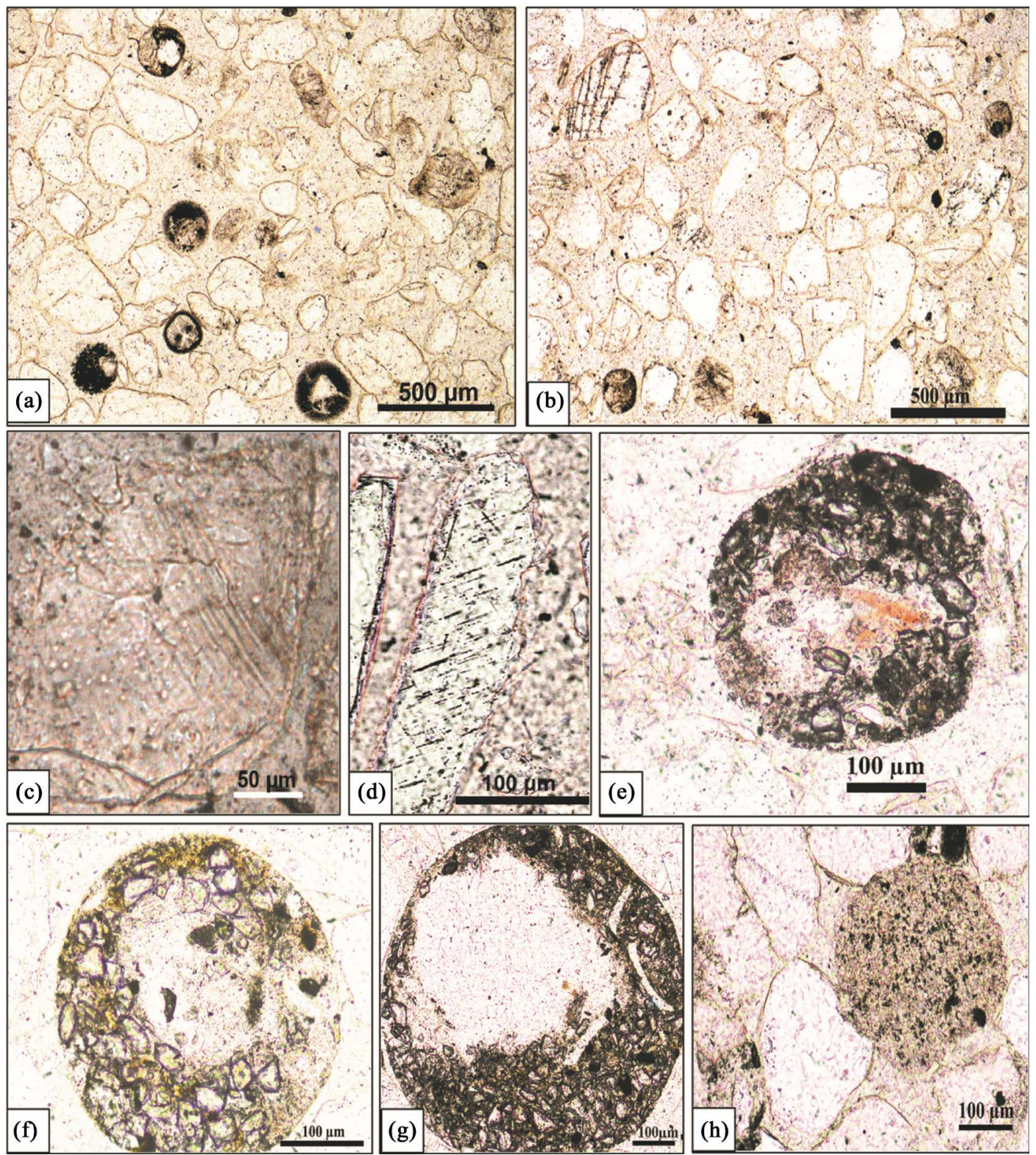

Figure 2. Photomicrographs of the studied glass particles-bearing sedimentary rocks. (a) Quartz grains displays brownish color with a cloudy and grainy appearance. Notice, large voids concentrated toward the microspherules edges, P.L. (b) Intensely fractured quartz grains display Boehm lamellae indicated by micro-inclusions. Notice, microspherules contain large voids concentrated toward their edges, P.L. (c) Apparently curved deformed quartz grain display superficial PDFs, P.L. (d) Deformed quartz with two sets of PFs comprise planar thin parallel-walled fissures exhibited by the fluid inclusion trails. ((e)-(g)) Microspherules composed of homogeneous glass encloses anhedral quartz crystals and show a big hollow at the center, P.L. (h) Glass microspherule is partially to completely altered to clay, P.L.

Binocular microscopy investigation showed that the quartz grains of the friable sandstone samples have milky color and transparent appearance (Figure 3(a)). It also showed that the mineral inclusions within some quartz grains are black (Figure 3(a)) or brown and exhibit a variety of shapes and sizes.

HRTEM investigation showed the internal structure and mineral inclusion in the quartz grains (Figure 4(a)) and clarified the nanostructure intergrowth pattern of polycrystalline diamond aggregates in the SiC (Figure 4(b)). The granular texture of the polycrystalline impact diamond that comprises numerous rounded individual crystallites was observed under HRTEM (Figure 4(c)). It also showed the porous micro-texture of the studied compact polycrystalline impact microdiamond (Figure 4(d), Figure 4(e)). Compact polycrystalline diamond 
displays a cubic aggregate pattern (Figure 4(d), Figure 4(e)). HRTEM investigation showed a diffraction pattern confirming nanocrystalline microdiamond structure (Figure 4(e)).

SEM investigation revealed that most of the quartz grains display etched, pitted and broken surfaces. Also, the
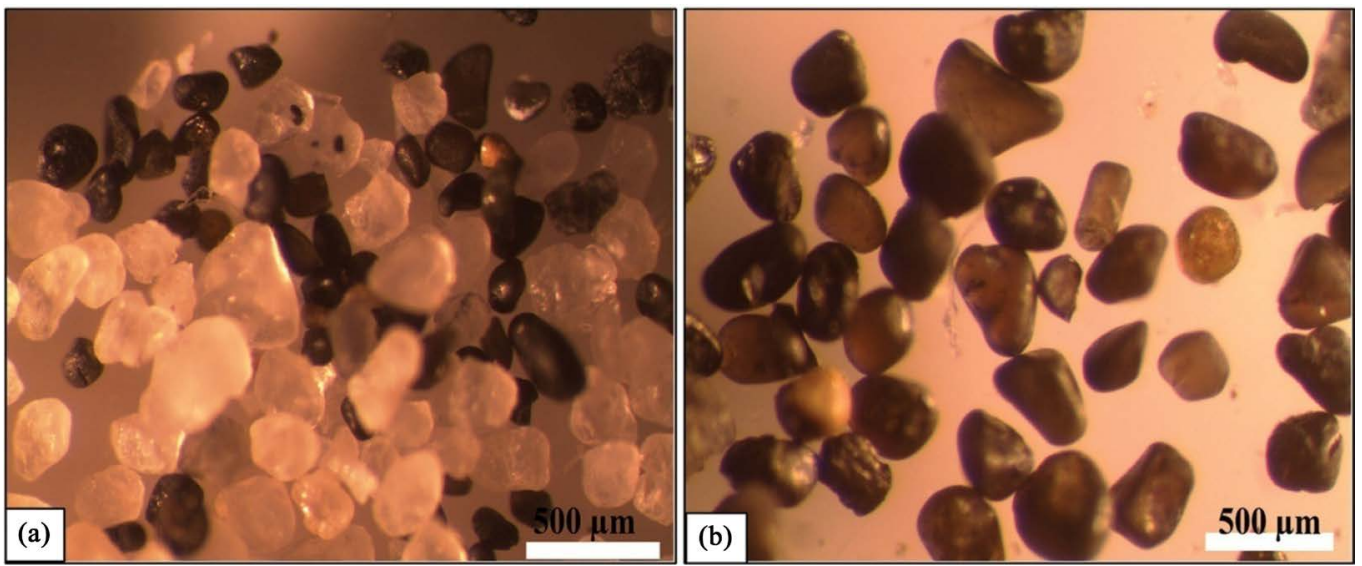

Figure 3. Binocular stereomicroscope photomicrographs of the glass microspherules and quartz grains. ((a), (b)) Black opaque glass microspherules. Notice, non-opaque varieties are transparent to translucent and display multiplicity colors as brown, amber and yellowish brown. They exhibit rods, teardrop-shaped and sphere forms. Glass microspherules are lustrous with shiny, smooth to frosted and rough surface texture. Quartz grains are milky and transparent and enclose black inclusions (Figure 3(b)).
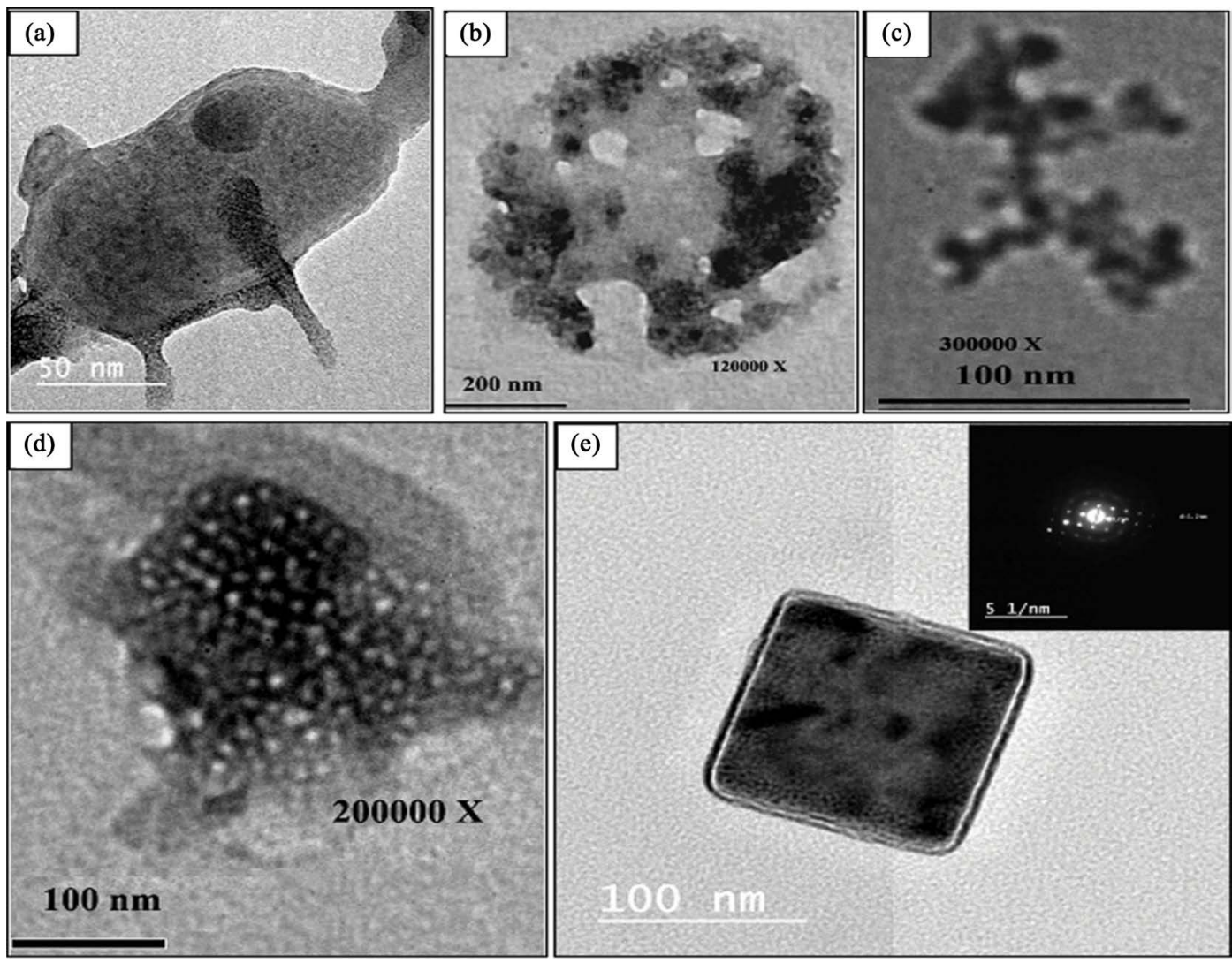

Figure 4. HRTEM photomicrographs of (a) Quartz grains enclose black inclusions. (b) Nanostructure intergrowth pattern of $\mathrm{SiC}$ and microdiamond aggregates. (c) Granular texture of the polycrystalline impact diamond comprising numerous rounded individual crystallites. ((d), (e)) Porous polycrystalline microdiamond. Notice, the cubic pattern of the microdiamond aggregates. Also, the diffraction pattern confirms the nanocrystalline structure of the microdiamond. 
recorded glass microspherules have been etched and exhibit a variety of grooves, notches, radial gouges nanostructure patterns and bubble-like pits (Figures 5(a)-(c)). Star-shaped aggregates are occasionally recognized on the surface of some glass microspherules (Figure 5(d)). Also, SEM investigation elucidated the surface features of the $\mathrm{SiC}$ and the associated microdiamond nanoparticles aggregates (Figure 5(e), Figure 5(f)).

\subsection{Geochemistry}

In general impact spherules are rich in $\mathrm{SiO}_{2}(58 \%$ - 85\%). They are mostly free of primary crystallites and relic grains [29], except for quartz and cristobalite inclusions reported in a few North American microtektites from the Caribbean Sea and Gulf of Mexico [30]. Recently, [31] reported the occurrence of microscopic inclusions of shocked quartz and $\mathrm{Zr}$ phase besides trace of Fe oxides crystallites in Australian microtektites recovered from deep-sea sediment cores within $2000 \mathrm{~km}$ of Indonesia.

The studied glass microspherules have a broad variety in silica and major oxide content (Table 1) that reaches almost $100 \%$. The oxides, total near $100 \%$ indicates that the glass volatile content is low [22].
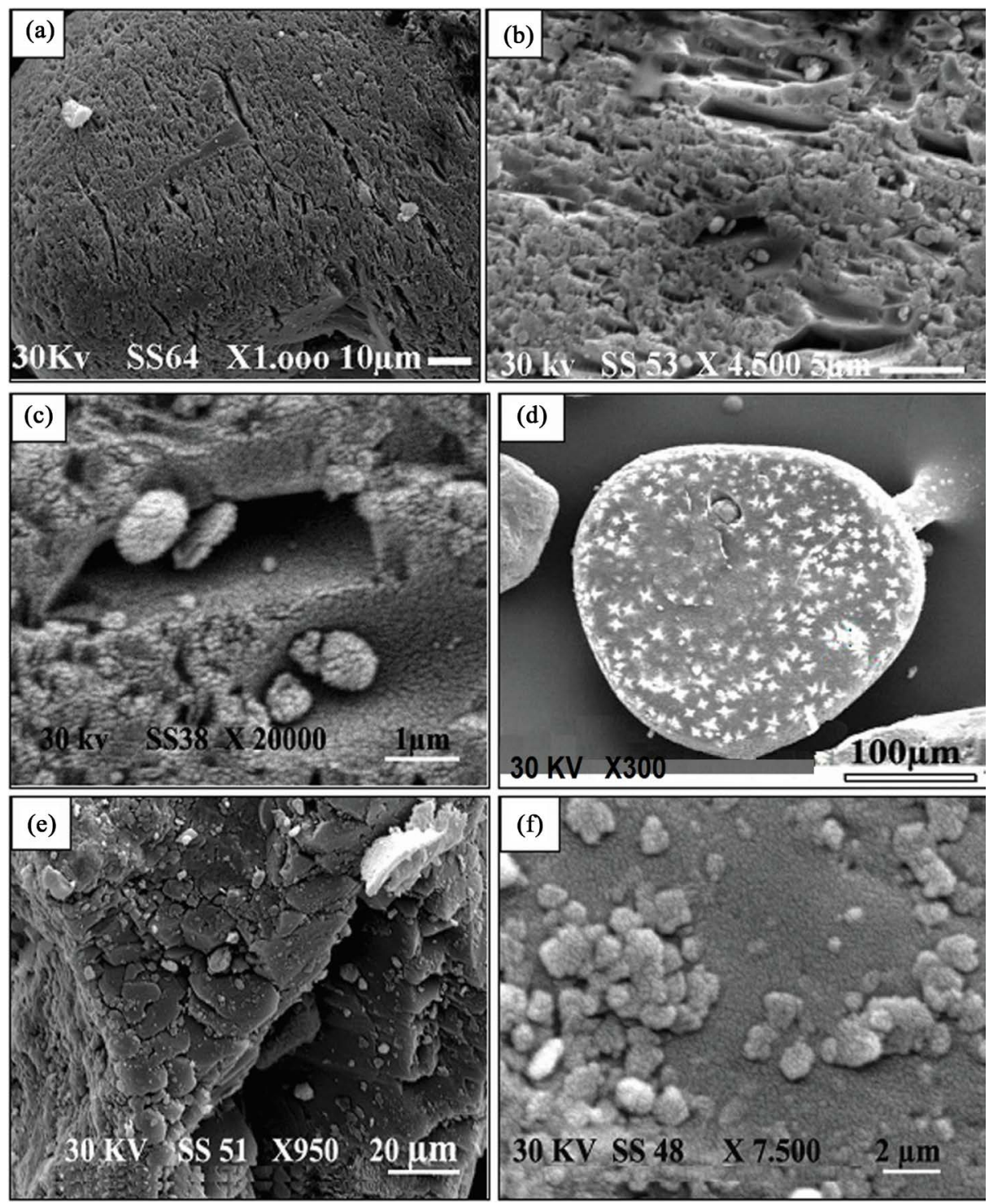

Figure 5. SEM photomicrographs of (a) Glass microspherules show grooves, gouges and nanostructure pattern. ((b), (c)) Texture of microspherule. (d) Star-shaped aggregates recognized on the surface of glass microspherules. ((e), (f)) Ovoid to elongate nanoparticles of microdiamond on the surface of SiC fragment. 
Table 1. Major oxide composition (\%) of the studied glass microspherules and associated quartz.

\begin{tabular}{|c|c|c|c|c|c|c|c|c|c|}
\hline No. & $\mathrm{SiO}_{2}$ & $\mathrm{Al}_{2} \mathrm{O}_{3}$ & $\mathrm{FeO}$ & $\mathrm{MgO}$ & $\mathrm{CaO}$ & $\mathrm{Na}_{2} \mathrm{O}$ & $\mathrm{TiO}_{2}$ & $\mathrm{Cl}$ & $\mathrm{C}$ \\
\hline 1 & 40 & 31.57 & 20.88 & 5.61 & - & - & 1.94 & - & - \\
\hline 2 & 38.84 & 25.18 & 30.67 & 5.32 & - & - & - & - & - \\
\hline 3 & 42.68 & 29.97 & 23.08 & 4.27 & - & - & - & - & - \\
\hline 4 & 43.17 & 29.69 & 22.18 & 4.96 & - & - & - & - & - \\
\hline 5 & 43.74 & 31.07 & 19.88 & 5.32 & - & - & - & - & - \\
\hline 6 & 42.15 & 30.02 & 19.22 & 5.21 & - & - & 3.4 & - & - \\
\hline 7 & 38.64 & 32.14 & 22.22 & 4.9 & - & - & 2.09 & - & - \\
\hline 8 & 37.79 & 29.22 & 32.99 & - & - & - & - & - & - \\
\hline 9 & 32.57 & 25.77 & 33.15 & 4.2 & 1.39 & - & 2.92 & - & - \\
\hline 10 & 69.78 & - & 11.99 & 13.17 & 5.06 & - & - & - & - \\
\hline 11 & 52.14 & 18.25 & 26.77 & 2.83 & - & - & - & - & - \\
\hline 12 & 45.65 & 30.29 & 14.05 & 7.57 & - & 2.03 & - & 0.42 & - \\
\hline 13 & 39.95 & 25.99 & 16.22 & 5.93 & - & 8.98 & - & 2.93 & - \\
\hline 14 & 43.81 & 28.63 & 14.31 & 7.19 & - & 4.86 & - & 1.21 & - \\
\hline 15 & 40.38 & 26.71 & 16.64 & 6.73 & - & 7.63 & - & 2 & - \\
\hline 16 & 56.99 & 28.11 & 14.15 & 0.76 & - & - & - & - & - \\
\hline 17 & 20.85 & - & - & - & - & - & - & - & 79.15 \\
\hline 18 & 26.98 & - & - & - & - & - & - & - & 73.02 \\
\hline 19 & 44.15 & - & - & - & - & - & - & - & 55.85 \\
\hline 20 & 47.13 & - & - & - & - & - & - & - & 52.87 \\
\hline 21 & 70.89 & - & - & - & - & - & - & - & 29.11 \\
\hline 22 & 76.86 & - & - & - & & - & - & - & 23.14 \\
\hline 23 & 84.21 & - & - & - & - & - & - & - & 15.79 \\
\hline 24 & 38.1 & 27.62 & - & - & - & - & - & - & 34.28 \\
\hline 25 & 50.11 & - & - & - & - & - & - & - & 49.89 \\
\hline 26 & 98.63 & 0.88 & 0.4 & 0.09 & - & - & - & - & - \\
\hline 27 & 99.92 & - & 0.08 & - & - & - & - & - & - \\
\hline 28 & 100 & - & - & - & - & - & - & - & - \\
\hline 29 & 100 & - & - & - & - & - & - & - & - \\
\hline
\end{tabular}

Note: No. 1-11: glass microspherules, No. 12-16: microspherules with star-shaped aggregates, No. 17-25: Silicon carbides and associated microdiamond, No. 26-29: Pure and impure quartz.

Frequently microtektites have a broad range of composition with high oxide and low silica contents. Based on silica content, the studied glass microspherules can be classified into silica-rich $(>50 \%)$ and silica-poor $(<50 \%)$ groups. The $\mathrm{SiO}_{2}$ contents range from $32.57 \%$ to $69.78 \%$ (Table 1). The studied glass microspherules are also characterized by high $\mathrm{Al}_{2} \mathrm{O}_{3}$ and $\mathrm{FeO}$ contents and low $\mathrm{CaO}$ and $\mathrm{MgO}$ contents (Table 1). $\mathrm{Al}_{2} \mathrm{O}_{3}$ and $\mathrm{FeO}$ are generally negatively correlated with $\mathrm{SiO}_{2}$ contents. However, the inverse relationship between major oxides and $\mathrm{SiO}_{2}$ is frequently documented and typically interpreted for Cenozoic tektite glass [22]. Contrary to the truly hyaline glass microspherules, the semi-hyaline glass microspherules that contain star-shaped aggregates of crystallites contain a higher percent of $\mathrm{Na}_{2} \mathrm{O}$ (Table 1).

Impact glass resembles the obsidian volcanic glass in several petrographic aspects, but can be distinguished from it by its range of chemical composition and isotopic signatures [22] as well as its association with shocked metamorphosed minerals and carbon-rich particles.

The studied SiC contains variable percentages of $\mathrm{SiO}_{2}(20.85 \%-84.21 \%)$ and carbon $(15.79 \%-79.15 \%)$. The investigated nanoparticles of $\mathrm{SiC}$ show a high percent of carbon, indicating intergrowth of microdiamond aggregates within the SiC internal structure (Figure 4(b)). 
Chemical analysis for the host white sandstone shows that some of the quartz grains contain traces of $\mathrm{Al}_{2} \mathrm{O}_{3}$, FeO and MgO while others are entirely composed of pure silica (analyses no. 26 and 29, Table 1).

\section{Discussion}

Generally, Jurassic-Cretaceous (J/K) boundary represented a period of global geological upheavals and environmental disturbance which includes large meteorite impacts, submarine volcanism and climatic changes [32]. Since the glass spherules are among the physical tracers of a cosmic impact, the present work assigned the preserved glass microspherules within the white sandstone sediments of the Malha Formation to a cosmic event rather than to a cosmic ablation event, which generates ablation spherules or to a melting of micrometeorites, which generates cosmic spherules.

As the impact glass spherules were condensed from vapor plumes or separated from impact melt produced during the collision of asteroids and comets with earth, they could be considered extraterrestrial in origin. The studied microspherules resemble microtektites in which a small extraterrestrial component is intimately mixed with terrestrial materials from target rocks. This mixing led to a major element composition that differ extensively from chondritic composition [15], allowing them to be distinguished from cosmic spherules [33].

The microtektite particles were formed by melting of shallow target rocks and were transported as an ejecta curtain, while shocked quartz grains were derived as a fireball from the affected deep material of the target rocks [34]. Superficial markings of the microtektites designate a high-velocity path of the glass microspherules through the atmosphere, which were completely sculpted aerodynamically before they arrived at the ground [27].

In west central Sinai, the high content of $\mathrm{Al}_{2} \mathrm{O}_{3}$ in the microtektite-like microspherules supports a clay-rich target rock, while lower percentages of $\mathrm{Ca}$ and $\mathrm{Mg}$ indicate that the target was sedimentary rock interbedded with thin carbonate layers. The source of studied microtektites is attributed to the melting of a sandstone rich in clay and organic matter. Siliciclastic rocks of the Paleozoic period in west central Sinai typified the characteristics of such target rock [28] [35] [36]. The high content of FeO in the glass microspherules may be explained by admixture with projectile matter [37].

Quartz grains containing a single set of deformation lamellae that bear only superficial resemblance to those produced by shock are recorded with the studied glass microspherules. Also, intensely fractured shattered quartz is ubiquitous in Malha white sandstone. While not representing equivocal shock metamorphic indicators, theses shattered quartzes are similar to those observed in the target rocks of the Libyan Desert glass, which formed via an impact event [38]. Planar fractures occur frequently in shocked quartz, but are not considered a shock diagnostic unless occurring with the associated PDFs [8]. Although the irregular fractures or their inclusions trials in quartz grains are still not supported an impact origin, they occur along with non-planar microdeformation features in impact affected rocks, e.g., at Vredefort [26]. However, planar microdeformation features and irregular fractures develop in silicate minerals as a result of shock compression during the impact event [39]. The brown coloration of recorded quartz that resembles toasted quartz is attributed to the submicron scale fluid inclusions trapped during crystal growth [40].

Generally, the recognition of obvious indicators of shock metamorphism in minerals, such as PDFs and diaplectic glass, is absent in the impact sites developed in unconsolidated sedimentary rocks [41]. This is a difficult and unsolved problem and one that has gotten relatively little attention thus far [42]. However, Boehm lamellae in the quartz grains signify a high-stress regime, indicating a probable metamorphic origin, while PDFs indicates shock metamorphism via impact.

Silicon carbides associated with studied glass microspherules were formed at temperatures more than $1000^{\circ} \mathrm{C}$. When the evaporated silica atoms from the target substrate react with carbon, as the amount of carbon increases relative to silica, the diamond is formed. The association of SiC and diamond, both as integrate and separate crystals has been covered from the Ries Crater in Germany and it was seen as a product of the chemical vapor deposition-like mechanism [43]. The recognition of SiC intergrowth with microdiamond aggregates in sedimentary rocks of west central Sinai supports their origin from the impact event via rapid condensation and growth within a vapor phase as a result of extraterrestrial bolide stroked a target rock rich in carbonaceous matter. Hence, the organic matter was converted to $\mathrm{SiC}$ and/or microdiamond. Possibly a derivation of the polycrystalline texture of the diamond was resulted either of the shock transformation, with the nucleation of individual crystallites or inherited from the pre-shock structure [43].

Recrystallization and transformation of the topmost sandstone bed to quartzite strengthen the impact event 
origin. One of the unusual shock effects is shock lithification and production of instant rock, whereby unconsolidated quartz sands are compacted into coherent sandstone like lithologies [42].

We urge that further field work must be carried out in the study area and the surrounding areas to expose the site of the source impact crater, which might lie undiscovered somewhere in Sinai. As well, it is required to establish whether the recorded glass microspherules were formed from large air burst or from hypervelocity impacting. However, silicate dominated impact spherules, associated with large impacts, are stratigraphically restricted; therefore impact spherules can be distinguished on the bases of their localized temporal, spatial and chemical distribution [33]. Impact glasses that lack typical shock metamorphic indicators are similar to other impact glasses that lack confirmed source craters and that likely formed from volatile-rich target rocks (e.g., [38]). Nevertheless the study area was affected by cosmic impact that resulted in the production of glass microspherules enclosing mineral fragments of the target rocks. The occurrence of microscopic relict inclusions in microtektites denotes the proximity to the source crater [31].

\section{Conclusions}

In spite of the fact that no source crater has been recognized to date in the studied area, the authors propose at least a single impact event scenario for the impact glass microspherules in west central Sinai. This proposal is strengthened by the evidences related to the geochemistry and micro-texture of the recognized glass microspherules and associated textures. The evidences include:

1) Abundance of shattered quartz grains.

2) $\mathrm{Al}_{2} \mathrm{O}_{3}$ content in the glass microspherules reaches $32 \%$, which is unlike any known volcanic glass.

3) $\mathrm{FeO}$ content in the glass microspherules reaches $33 \%$ indicating admixing with projectile matter.

4) Presence of microdiamond intergrowth with SiC.

5) Inclusion of microscopic relict grains of the target rocks within the glass microspherules.

6) Major element composition that differs extensively from chondritic meteorites.

The proposed scenario of the cosmic impact event in west central Sinai comprises the following sequence of depositional events: the impact excavated the Paleozoic siliciclastic sedimentary rocks and led to the ejection of impact glass microspherules from the place of impact followed by shattered quartz. The deposition of microtektite-like glass particles within the white sandstone beds of the Malha Formation took place in the fluvial plain terrestrial environment. This setting precluded harsh post-depositional reworking and maintained the preservation of the glass particles as a primary layer. Eventually, lateral migration of the braided channels led to the reworking of the microspherules layer and the spatial dispersal of the shattered quartz.

\section{Acknowledgements}

This work is supported by the Faculty of Science, Beni-Suef University. Author's gratitude to Mr. Hossam Hamied, engineer in SIBELCO-Egypt, for his assistance during the field work. The authors also thank Mr. Moustafa Ragab for his help during collection of samples in the field. Acknowledgment is extended to Mr. Ali Hassan and Miss Amal Mokhatar, analytical lab technicians, Faculty of Science, Beni-Suef University. Particular thanks to Dr. Mahmoud Hassan, HRTEM lab technician at NRC for his kind assistance during the laboratory work. Special gratitude to Miss Howida Abdel Tauab, technician in binocular stereomicroscope lab at EMRA for her kind assistance. The authors would like to thank Dr. Christopher Hamann, MFN, Berlin, Germany, for constructive comments and suggestions that significantly improved the former edition of the manuscript.

\section{References}

[1] Kyte, F.T. (2002) Tracers of the Extraterrestrial Component in Sediments and Inferences for Earth's Accretion History. In: Koeberl, C. and MacLeod, K.G., Eds., Catastrophic Events and Mass Extinctions: Impacts and Beyond, Boulder, Colorado, Geological Society of America, Special Paper No. 356, 21-38. http://dx.doi.org/10.1130/0-8137-2356-6.21

[2] Guaita, C. and Martegani, F. (2008) Cosmic Microsphere: A Sem Study. Memorie Societa Astronemica Itallana Supplementi, 12, 110-125.

[3] Badyukov, D.D. and Raitala, J. (2012) Ablation Spherules in the Sikhote Alin Meteorite and Their Genesis. Petrology, 20, 520-528. http://dx.doi.org/10.1134/S086959111206001X

[4] Kohout, T., Kallonen, A., Suuronen, J.-P., Rochette, P., Hutzler, A., Gattacceca, J., Badjukov, D.D., Skála, R., Böhmová, V. and Čuda, J. (2014) Density, Porosity, Mineralogy and Internal Structure of Cosmic Dust and Alteration 
of Its Properties during High Velocity Atmospheric Entry. MAPS, 49, 1157-1170. http://dx.doi.org/10.1111/maps.12325

[5] Kleesment, A., Konsa, M., Puura, V., Karhu, J., Preeden, U. and Kallaste, T. (2006) Impact-Induced and Diagenetic Changes in Minerals in the Sandy Ejecta of Kärdla Crater, NW Estonia. Proceedings of the Estonian Academy of Sciences, Geology, 55, 189-212.

[6] Puura, V., Huber, H., Kirs, J., Kärki, A., Suuroja, K., Kirsimäe, K., Kivisilla, J., Kleesment, A., Konsa, M., Preeden, U., Suuroja, S. and Koeberl, C. (2004) Geology, Petrography and Geochemistry of Impactites and Target Rocks from Kärdla Crater, Estonia. Meteoritics and Planetary Science, 39, 425-451. http://dx.doi.org/10.1111/j.1945-5100.2004.tb00103.x

[7] Gucsik, A. (2009) Shock Metamorphism of Terrestrial Impact Structures and Its Application in the Earth and Planetary Sciences. Cathodoluminescence and Its Application in the Planetary Sciences. Springer-Verlag, Berlin Heidelberg, 23. http://dx.doi.org/10.1007/978-3-540-87529-1_2

[8] Ferrière, L., Morrow, J.R., Amgaa, T. and Koeberl, C. (2009) Systematic Study of Universal-Stage Measurements of Planar Deformation Features in Shocked Quartz: Implications for Statistical Significance and Representation of Results. Meteoritics and Planetary Science, 44, 925-940. http://dx.doi.org/10.1111/j.1945-5100.2009.tb00778.x

[9] French, B.M. and Koeberl, C. (2010) The Convincing Identification of Terrestrial Meteorite Impact Structures: What Works, What Doesn't and Why. Earth Science Reviews, 98, 123-170. http://dx.doi.org/10.1016/j.earscirev.2009.10.009

[10] Bunch, T.E., Hermes, R.E., Moore, A.M.T., Kennett, D.J., Weaver, J.C., Wittke, J.H., DeCarli, P.S., Bischoff, J.L., Hillman, G.C., Howard, G.A., Kimbel, D.R., Kletetschka, G., Lipo, C.P., Sakai, S., Revay, Z., West, A., Firestone, R.B. and Kennett, J.P. (2012) Very High-Temperature Impact Melt Products as Evidence for Cosmic Airbursts and Impact 12,900 Years Ago. PNAS PLUS, E1903-E1912. http://dx.doi.org/10.1073/pnas.1204453109

[11] Osinski, G.R., Haldemann, A.F.C., Schwarcz, H.P., Smith, J.R., Kleindienst, M.R., Kieniewicz, J. and Churcher, C.S. (2007) Impact Glass at the Dakhleh Oasis, Egypt: Evidences for a Cratering Event or Large Aerial Burst? Lunar and Planetary Science XXXVIII.

[12] Glass, B.P., Muenow, D.W. and Aggrey, K.E. (1986) Further Evidence for the Impact Origin of Tektites. Meteoritics, 21, 369-370.

[13] Kieffer, S.W. and Simonds, C.S. (1980) The Role of Volatiles and Lithology in the Impact Cratering Process. Reviews of Geophysics and Space Physics, 18, 143-181. http://dx.doi.org/10.1029/RG018i001p00143

[14] Artemieva, N., Pierazzo, E. and Stöffer, D. (2002) Numerical Modeling of Tektite Origin in Oblique Impacts: Implication to Ries Moldavites Strewn Field. Bulletin of the Czech Geological Survey, 77, 303-311.

[15] Glass, B.P. (1990) Tektites and Microtektites: Key Facts and Inferences. Tectonophysics, 171, 393-404. http://dx.doi.org/10.1016/0040-1951(90)90112-L

[16] Koeberl, C. (1994) Tektite Origin by Hypervelocity Asteroidal or Cometary Impact: Target Rocks, Source Craters, and Mechanisms. Geological Society of America Special Paper, 293, 133-152. http://dx.doi.org/10.1130/SPE293-p133

[17] McHugh, C.M.G., Snyder, S.W., Deconinck, J.F., Saito, Y., Aubry, M.P. and Katz, M.E. (1996) Upper Eocene Tektites of the New Jersey Continental Margin: ODP, Site 904. Proceedings of the Ocean Drilling Program, Scientific Results Vol. 150, College Station, 241-269. http://dx.doi.org/10.2973/odp.proc.sr.150.019.1996

[18] Fröhlich, F., Poupeau, G., Badou, A., Bourdonnec, L.E., Sacquin, F.X., Dubernet, Y., Bardinzeff, S., Véran, J.M., Smith, M.D.C. and Diemer, E. (2013) Libyan Desert Glass: New Field and Fourier Transform Infrared Data. Meteoritics and Planetary Science, 48, 2517-2530. http://dx.doi.org/10.1111/maps.12223

[19] Folco, L., DiMartino, M., El Barkooky, A., D’Orazio, M., Lethy, A., Urbibi, S., Nicolosi, I., Hafez, M., Cordier, C., Van Ginneken, M., Zeoli, A., Radwan, A.M., El Khrepy, S., El Gabry, M., Gomaa, M., Barakat, A.A., Serra, R. and El Sharkawi, M. (2010) The Kamil Crater in Egypt. Science, 329, 804. http://dx.doi.org/10.1126/science.1190990

[20] Johnson, D. and Tyldesley, J. (2013) Iron from the Sky: Meteorites in Ancient Egypt. Meteorite, 4, 8-13.

[21] Bignami, L., Guaita, C., Pezzotta, F. and Zilioli, M. (2014) Micro-Spherules near the Kamil Crater. Memorie della Societa Astronomica Italiana Supplementi, 26, 25-37.

[22] Claeys, P. and Casier, J.G. (1994) Microtektite-Like Impact Glass Associated with the Fransnian-Famennian Boundary Mass Extension. Earth Planetary Science Letters, 122, 303-315. http://dx.doi.org/10.1016/0012-821X(94)90004-3

[23] Wopfner, H. (2010) Burial History of Jurassic Gondwana Surface West and Southwest of Lake Eyre, Central Australia. Coruña, 35, 221-242.

[24] Alsharhan, A.S. and Salah, M.G. (1997) Lithostratigraphy and Hydrocarbon Habitat of the Pre-Cenomanian Nubian Sandstone in the Gulf of Suez Oil Province, Egypt. GeoArabia, Bahrian, 2, 385-400.

[25] El-Azaby, M.H. and El-Araby, A. (2005) Depositional Facies, Environments and Sequence Stratigraphic Interpretation of the Middle Triassic-Lower Cretaceous (Pre-Late Albian) Succession in Arif El-Naga Anticline, Northeast Sinai, 
Egypt. Journal of African Earth Science, 41, 119-143. http://dx.doi.org/10.1016/j.jafrearsci.2005.02.005

[26] Reimold, W.U., Ferrière, L., Deutsch, A. and Koeber, C. (2014) Impact Controversies: Impact Recognition Criteria and Related Issues. Meteoritics and Planetary Science, 49, 2037-2087. http://dx.doi.org/10.1111/maps.12284

[27] Sweeney, D. and Simonson, B.M. (2008) Textural Constraints on the Formation of Impact Spherules: A Case Study from the Dales Gorge BIF, Paleoproterozoic Hamersley Group of Western Australia. Meteoritics and Planetary Science, 43, 2073-2087. http://dx.doi.org/10.1111/j.1945-5100.2008.tb00662.x

[28] Kassab, M.A., Hassanani, I.M. and Salem, A.M. (2014) Petrography, Diagenesis and Reservoir Characteristics of the Pre-Cenomanian Sandstone, Sheikh Attia Area, East Central Sinai, Egypt. Journal of African Earth Science, 96, 122 138. http://dx.doi.org/10.1016/j.jafrearsci.2014.03.021

[29] Glass, B.P. (1982) Possible Correlation between Tektite Events and Climatic Changes. Geological Society of America Special Paper, 190, 251-258. http://dx.doi.org/10.1130/SPE190-p251

[30] Glass, B.P. and Zwart, M.J. (1979) North American Microtektites in Deep Sea Drilling Project Cores from the Caribbean Sea and Gulf of Mexico. Geological Society of American Bulletin, 90, 595-602. http://dx.doi.org/10.1130/0016-7606(1979)90<595:NAMTID>2.0.CO;2

[31] Folco, L., Perchiazzi, N., D’Orazio, M., Frezzotti, M.L., Glass, B.P. and Rochette, P. (2010) Shocked Quartz and other Mineral Inclusions in Australasian Microtektites. Geology, 38, 211-214. http://dx.doi.org/10.1130/G30512.1

[32] Misra, S., Mazunder, A., Andreoli, M.A. and Ray, D. (2014) Large Meteorite Impacts, Volcanism and Possible Environmental Disruption at the Jurassic-Cretaceous Boundary. 45th Lunar and Planetary Science Conference, Woodland.

[33] Genge, M.J., Engrand, C., Gounelle, M. and Taylor, S. (2008) The Classification of Micrometeorites. Meteoritics and Planetary Science, 43, 497-515. http://dx.doi.org/10.1111/j.1945-5100.2008.tb00668.x

[34] Alvarez, W., Claeys, P. and Kieffer, S.W. (1995) Emplacement of Cretaceous-Tertiary Boundary Shocked Quartz from Chicxulub Crater. Science (New Series), 269, 930-935. http://dx.doi.org/10.1126/science.269.5226.930

[35] Temraz, M.G. (2012) Mineralogical and Physical Characteristics of White Sandstone of Abu Rodeiyim Quarry (Sinai), and its Possible Industrial Utilization. Acta Geological Sinica, 86, 440-446. http://dx.doi.org/10.1111/j.1755-6724.2012.00672.x

[36] Kora, M. and Schultz, G. (1987) Lower Carboniferous Palynomorphs from Um Bogma, Sinai (Egypt). Grana, 26, 5366. http://dx.doi.org/10.1080/00173138709428904

[37] Schulte, P., Deutsch, A., Salge, T., Berndt, J., Kontny, A., Macleod, K.G., Neuser, R.D. and Krumm, S. (2009) A Dual-Layer Chicxulub Ejecta Sequence with Shocked Carbonates from the Cretaceous-Paleogene (K-Pg) Boundary, Demerara Rise, Western Atlantic. Geochimica et Cosmochimica Acta, 73, 1180-1204. http://dx.doi.org/10.1016/j.gca.2008.11.011

[38] Kleinmann, B., Horn, P. and Langenhorst, F. (2001) Evidence for Shock Metamorphism in Sandstones from the Libyan Desert Glass Strew Field. Meteoritics and Planetary Science, 36, 1277-1282. http://dx.doi.org/10.1111/j.1945-5100.2001.tb01960.x

[39] Langenhorst, F. and Deutsch, A. (2012) Shock Metamorphism of Minerals. Elements, 8, 31-36. http://dx.doi.org/10.2113/gselements.8.1.31

[40] Whitehead, J., Spray, J. G. and Grieve, R. (2002) Origin of Toasted Quartz in Terrestrial Impact Structures. Geology 30, 431-434. http://dx.doi.org/10.1130/0091-7613(2002)030<0431:OOTQIT>2.0.CO;2

[41] Ding, Y. and Veblen, D. R. (2004) Impactite from Henbry, Australia. American Mineralogist, 89, 961-968. http://dx.doi.org/10.2138/am-2004-0705

[42] Osinski, G. R., Grieve, R. A. F. and Spray, J. G. (2008) Impact Melting in Sedimentary Target Rock: An Assessment. Geological Society of America Special Paper, 437, 1-18. http://dx.doi.org/10.1130/2008.2437(01)

[43] Abbott, J. I. (2000) Carbon Chemistry of Giant Impacts. PhD Thesis, the Open University, Milton Keynes. 


\section{Submit or recommend next manuscript to SCIRP and we will provide best service for you:}

Accepting pre-submission inquiries through Email, Facebook, LinkedIn, Twitter, etc.

A wide selection of journals (inclusive of 9 subjects, more than 200 journals)

Providing 24-hour high-quality service

User-friendly online submission system

Fair and swift peer-review system

Efficient typesetting and proofreading procedure

Display of the result of downloads and visits, as well as the number of cited articles

Maximum dissemination of your research work

Submit your manuscript at: http://papersubmission.scirp.org/ 